\title{
ASSESSMENT OF PORT SUSTAINABILITY INDICATORS IN THE SUSTAINABILITY REPORTING PROCESS
}

\author{
Nergis ÖZISPA $^{1}$ and Gamze ARABELEN ${ }^{2}$
}

Keywords: Port Sustainability Indicators (PSIs), Port Sustainability Measurement, Seaports, Sustainability Reporting

\section{INTRODUCTION}

Sustainability for the port industry has become a growing source of fear and concern for port authorities, policy makers, port users and local communities (Acciaro et al., 2014). Ports composed of different businesses dealing with different activities and offering a wide range of services (Hakam, 2015), are among the most harmful to the environment due to their characteristics such as the amount of waste they produce, harmful emissions and noise pollution they cause (Darbra et al., 2015). To reduce this harm, sustainability is one of the important concepts for port industry (Broesterhuizen et al, 2012). Especially environmental issues in port industry, have become an increasingly important focus in a global trend recently (Shiau and Chuang, 2015) at the end port authorities are began to pay increasing attention to environmental sustainability and security issues (Bergmans et al., 2014). Thus, the purpose of this study is to determine the prevalently used port sustainability indicators (PSIs) in the sustainability reporting process.

\section{LITERATURE REVIEW}

Sustainability concept is mainly assumed to have originated in the (1987) Brundtland Report called "Our Common Future"' by the United Nations World Commission on Environment and Development (Yadava and Sinha, 2014). The Brundtland commission report also has the most quoted definition of sustainability which is (Hernández et al., 2012): "Sustainable development is development that meets the needs of the present without compromising the ability of future generations to meet their own needs" (Brundtland Report, 1987). Sustainability issues have become a directory principle and aim for human and economic development over the past 30 years since the publication of the Brundtland Report in the 1987.

\footnotetext{
1 Araş.Gör., Dokuz Eylül Üniversitesi, Denizcilik Fakültesi, İzmir nergis.ozispa@deu.edu.tr.

${ }^{2}$ Yrd. Doç. Dr., Dokuz Eylül Üniversitesi, Denizcilik Fakültesi, İzmir gamze.arabelen@deu.edu.tr.
} 
The use of indicators has become standard method to measure sustainability after the publication of the Brundtland Commission Report in 1987 and the Earth Summit in 1992 (Milman and Short, 2008). Sustainability must be taken into account and be found a balance between environmental, financial and social factors that are also referred as the triple bottom line of sustainability (Sislian et al., 2016) or called three dimensions of sustainable development (Tanzil et al., 2006). Similar to sustainability indicators, PSIs are also ensure a foundation to measure, monitor, and improve the sustainable development of ports (Shiau and Chuang, 2015). Key PSIs used to measure port sustainability and sustainable development of an industry (Tanzil et al., 2006).

Sustainability reporting is such an implementation of measuring and being accountable to internal and external stakeholders for organizational performance to the aim of sustainable development (Yadava and Sinha, 2014). In the 21. century it became a necessity to develop an indicator system for measuring, reporting, and monitoring port development to improve port sustainability for port operators (Shiau and Chuang, 2015) due to all emissions and pollutions caused by ports. Ports are increasingly under pressure to show especially their environmental sustainability situations (Darbra et al, 2005). Because of that, most of the literature has focused on developing indicators for measuring port environmental impacts; however, the social and financial aspects have been relatively ignored both measuring and reporting processes (Shiau and Chuang, 2015).

Turcu (2013) states that sustainability indicators are non-universal but useful for both measuring current progress and identify current problems. Addition that idea Hakam (2015) states that it is possible to decide which port is best performing, in other words determining the dominant value driver that will improve the ports performance with a minimum investment. Therefore, this study aims to propose a set of port sustainability indicators (PSIs) to the implementers in the sector which can be universal by determining the most mentioned indicators in the ports' sustainability reports.

\section{METHODOLOGY}

In this study, first, port sustainability indicators that focused on port sustainability measurement in current literature gathered together to obtain sub-dimensions. Then, 7 different ports sustainability reports which published in 2014 analyzed via the NVIVO 8 software programme according to the 3 dimensions of sustainability and their sub-dimensions obtained in the first part of the study. At the end, the most used and unused port sustainability indicators (PSIs) in the sustainability reporting process identified under the three main dimensions of sustainability; environmental, financial and social.

PSIs to be used in measuring the using frequency in ports sustainability reports are gathered together in several sources in current literature and in this study they will be named after sub-dimensions of PSIs. 
To gather these sub-dimensions, first, 34 expert based PSIs taken directly from the study of Shiau and Chuang (2015). In that study Shiau and Chuang, used rough sets theory (RST) to evaluate and simplify 110 initial PSIs and that 34 expert based PSIs were selected by a group of people that consist of the Taiwan International Ports Corporation (TIPC), academic researchers, and industry representatives. In current study, dimensions, that are in the form of formulas have been simplified aiming adapted to the suitable format. After that process 24 sub-dimensions obtained. 15 subdimensions are taken from Hakam (2015), in that study Hakam used a sustainability index that created for the given port and we took the dimensions which suit current study. Additionally, 8 sub-dimensions are taken from Tanzil et al., (2006). Tanzil gives a list consists of important aspects of sustainability used for starting point and used to develop sustainability indicators. In (2005) Peris-Mora et al., found 17 indicators to develop an environmental sustainability measuring system. In current study we used 5 of those indicators to use as sub-dimension. At the end of this process 52 sub-dimensions gathered. 28 of them are environmental sub-dimensions, 15 of them are financial sub-dimensions and 9 of them are social sub-dimensions.

\section{FINDINGS AND DISCUSSION}

When analyzed environmental dimension of sustainability in port sustainability reports, it is seen that Port of Coruna gave place 9 chosen environmental indicators in its sustainability report. Unfortunately, it is the biggest number of all 32 chosen environmental indicators. Also, no common indicator can be found in all seven ports sustainability reports and this makes impossible to make comparison between ports environmental sustainability performances. As we mentioned literature part of this study, ports known as one of the most polluting sectors, and therefore they provide an opportunity to reduce emissions significantly (Broesterhuizen et al., 2012). However, to start reduce emissions first we can measure and compare them indeed. Moreover, our expectation from all port managements is to give place 12 used environmental sustainability indicators in their sustainability reports to see, measure and compare their sustainability performances with each other.

Unfortunately, financial dimension of sustainability is barely analyzed in this study. It's because of the chosen indicators are too specific or financial dimension of sustainability in ports sustainability reports are too narrow. At the end three chosen financial indicators found and just one of them used for all seven ports, which is "revenue".

When analyzed social dimension of sustainability in port sustainability reports, vital indicators like security, safety and training are found all seven sustainability reports as a bright side of the study. In addition to that general frequencies of chosen social indicators are better than other two dimensions of sustainability in ports sustainability reports. Nearly all indicators are used by half of ports. That makes comparatively possible to compare ports social dimensions of sustainability with each 
other. Also it has been noticed that the "accident rate" indicator has never been used by any port in their sustainability reports. Due to its nature, this indicator has vital importance and it should be included all sustainability reports.

There are no universally used port sustainability indicators so all the indicators used in the study are based on the indicators obtained through analysis in the past port sustainability studies. Due to the nature of social sciences, subjectivity of the obtained data to a certain extent is seen as the limitation of study. 